\title{
MINIPIG AS A MODEL FOR DRUG METABOLISM IN MAN: COMPARISON OF IN VITRO AND IN VIVO METABOLISM OF PROPAFENONE
}

\author{
Eva Anzenbacherováa ${ }^{a}$ Pavel Anzenbacher ${ }^{b *}$, Zbyněk Svobodac ${ }^{c}$, Jitka Ulrichováa, \\ Jaroslav Květina ${ }^{\mathrm{c}}$, Jana Zoulovác ${ }^{\mathrm{c}}$, František Perlík ${ }^{\mathrm{d}}$, Jiřina Martínkováe
}

a Institute of Medical Chemistry and Biochemistry, Faculty of Medicine, Palacky University, Olomouc, Czech Republic;

$b \quad$ Institute of Pharmacology, Faculty of Medicine, Palacky University, Olomouc, Czech Republic,

c Institute of Experimental Biopharmaceutics, PRO.MED.CS Praha - Academy of Sciences Joint Institute,

Hradec Králové, Czech Republic,

${ }^{d}$ Institute of Pharmacology, $1^{\text {st }}$ Faculty of Medicine, Charles University, Prague, Czech Republic;

e Institute of Pharmacology, Faculty of Medicine, Hradec Králové, Charles University, Prague, Czech Republic e-mail anzen@tunw.upol.cz

Received: October 3, 2003; Accepted: October 24, 2003

Keywords: Cytochromes P450 / Minipig / Propafenone / Pharmacokinetics / Glucuronidation

To prove the suitability of minipigs as experimental animal in modeling of the drug metabolism and pharmacokinetics in man, propafenone metabolism in vitro at the microsomal level as well as propafenone pharmacokinetics in the minipig was studied. The results were compared with those obtained for humans. It can be concluded that whereas the microsomal in vitro system of minipig may be a good model for drug metabolism in the man, the pharmacokinetics in the whole organism is more complex reflecting differences in substrate specificities of many enzymatic and transport systems. In this particular case, it has been documented that the glucuronidation of propafenone principal metabolite (5-hydroxypropafenone) is more efficient in the minipig.

\section{INTRODUCTION}

The search for an ideal or almost ideal experimental model of drug pharmacokinetics in man continues as the rat and more generally rodent models were shown not to correspond well to the metabolic properties of human liver monooxygenases ${ }^{1,2}$ (cytochromes P450, abbrev. CYP). The importance of a proper model of drug metabolism by cytochromes $\mathrm{P} 450$ is given by the fact that the majority of drugs undergoing biotransformation is metabolized by these enzymes which are known to take part in many different reactions involving exogenous as well as endogenous substrates as e.g. prostaglandins or steroids ${ }^{3}$.

Minipigs are considered as experimental model in pharmacology for their apparent physiological as well as metabolic similarities to the man. Recently, metabolism of several compounds by minipig liver microsomes has been studied ${ }^{47}$ and properties of individual isolated liver cytochromes were described ${ }^{8}$ indicating that minipig-derived systems at the subcellular (microsomal) or molecular level can mimic these of the human origin. Moreover, a study on pharmacokinetics of two model drugs, atenolol and 5-aminosalicylic acid (5-ASA) as drugs undergoing small (atenolol) and extensive (5-ASA) first pass metabolism in liver, indicated that the minipig may give reasonable estimates of pharmacokinetic parameters comparable to these obtained in human'.
This paper is focused on metabolism of antiarrythmic drug propafenone both in vitro at the subcellular level as well as in vivo on the whole organism. Data obtained with experimental model (minipig) are compared with those obtained with in vitro human microsomal samples as well as with previously published results of bioequivalence study with propafenone ${ }^{10}$. Propafenone itself is a suitable drug for evaluation of interspecies differences in metabolism as it is extensively converted by CYP2D6 yielding the main metabolite, 5-hydroxypropafenone and by CYP3A4 together with CYP1A2 giving the minor metabolite, depropylpropafenone. Also, involvement of enzymes of the second phase of drug biotransformation, namely, UDP-glucuronosyltransferases, has been documented in propafenone metabolism in the man ${ }^{11}$.

\section{MATERIALS AND METHODS}

Materials. Propafenone (2'-(2-hydroxy-3-propylaminopropoxy)-3-phenylpropiophenone hydrochloride) was obtained from PRO.MED.CS Praha a.s. (Prague, CZ). Propanorm tab. (150 mg of propafenone hydrochloride) was of the same origin. All other chemicals were purchased from Sigma Aldrich (Prague, CZ) and were of the highest purity.

Methods. Microsomal fraction of minipig liver homogenate was prepared by differential centrifugation according 
to established procedure ${ }^{12}$. In the in vivo study, the experimental animals fasted overnight and $2 \mathrm{~h}$ after oral drug administration of propafenone $(300 \mathrm{mg})$. Blood samples were taken before drug intake and at defined intervals after drug administration from incannulated jugular vein. Experimental animals $(\mathrm{N}=6$, male castrates, age 6 months, weight average $24.5 \pm 1.5 \mathrm{~kg}$ ) were Brno white variety of Goettingen minipigs (Veterinary Medicine Research Institute, Brno, CZ) and their use was approved by local Ethic Committee. UDP-glucuronidase treatment of minipig samples was done after addition of acetate buffer to the plasma samples $(0.1 \mathrm{M}$ acetate buffer, $\mathrm{pH}$ 5.0). After adjustation of the $\mathrm{pH}$ to 5.0, glucuronidase (Sigma Aldrich, Prague, CZ) was added and the samples were incubated for $15 \mathrm{~h}$ at the $23^{\circ} \mathrm{C}$. The samples were subsequently analyzed as vide infra.

Liver microsomes of human origin were obtained by the same method as described above, the source of experimental material were organ donors and the use of the experimental material was approved by the Ethic Committee. The data for propafenone pharmacokinetics in man are based on bioequivalence study with Propanorm tab.(PRO.MED.CS, $300 \mathrm{mg}$ ) published earlier ${ }^{10}$.

Determination of propafenone and its metabolites was performed by an HPLC method of Kroemer et al. ${ }^{11}$ after an extraction procedure based on method of Vozeh et al. ${ }^{13}$. An endcapped LiChrospher 100 RP-18 column (Merck, Darmstadt, FRG) was used with a mobile phase of 0.01 tetrabutylammonium sulfate/methanol $(52: 48 \mathrm{v} / \mathrm{v})$. A Thermo Separation Products (San Jose, CA) HPLC system consisted of a P4000 quaternary pump, a SCM 400 degasser and of an AS 3500 autosampler. Details of the procedure and of the validation of the method are given elsewhere ${ }^{10}$. P450 content was determined by difference spectroscopy ${ }^{12}$, protein assay was done by biscinchonic acid method using a set supplied by Pierce (Rockford, IL).

\section{RESULTS AND DISCUSSION}

\section{Liver microsomal fractions}

The basic characteristics of microsomal preparations of both minipig and human origin together with their respective activities in converting propafenone to metabolites are given in Tab. 1. It can be seen that the minipig microsomes formed much more homogenous set of samples with respect to cytochrome P450 content. Similar conclusion can be drawn out from the results on activities of microsomal fractions of minipig and human liver. As it has been mentioned in the Introduction, the two most important activities with respect to propafenone metabolism correspond to the formation of two metabolites, the major one being the 5-hydroxypropafenone and the minor one determined as the depropylpropafenone. 5-hydroxylation of the parent compound has been shown to be catalyzed specifically by the CYP2D6 form of cytochrome P450 ${ }^{11}$. One human sample apparently corresponded to a poor metabolizer with respect to CYP2D6 (sample No 4). The respective CYP2D6-mediated activity was extremely low which was reflected in low value of the respective activity. Apparently, due to this sample the variability of the 5-hydroxylating activity was relatively large. On the contrary, the corresponding activity in minipig microsomes did not vary in such an extent (Fig. 1). This may be explained by the fact that the minipigs were of the same breed which made their phenotype more homogenous. Fig. 1 also documents that the microsomal fraction of minipig origin may be a reasonable model for human metabolism as the values of both activities does not significantly differ.

Table 1. Basic characteristics of microsomal preparations of minipig and human origin.

\begin{tabular}{ccccc}
\hline $\begin{array}{c}\text { Sample } \\
\text { No. }\end{array}$ & $\begin{array}{c}\text { P450 } \\
{[\mu \mathrm{M}]}\end{array}$ & $\begin{array}{c}\text { Protein } \\
{[\mathrm{mg} / \mathrm{ml}]}\end{array}$ & $\begin{array}{c}\text { 5-hydroxylation } \\
\text { activity (CYP2D6) } \\
{[\mathrm{pmol} / \mathrm{min} / \mathrm{nmol} \mathrm{P450]}}\end{array}$ & $\begin{array}{c}\text { N-depropylation activity } \\
\text { (CYP3A4, CYP1A2) } \\
{[\mathrm{pmol} / \mathrm{min} / \mathrm{nmol} \text { P450] }}\end{array}$ \\
\hline Minipig & & & & 58.7 \\
1 & 14.5 & 15.2 & 57.2 & 29.2 \\
2 & 14.7 & 16.8 & 40.2 & 40.4 \\
3 & 14.6 & 13.6 & 56.0 & 30.1 \\
4 & 17.0 & 19.0 & 41.0 & 37.4 \\
5 & 20.2 & 15.6 & 68.0 & 102.8 \\
6 & 46.5 & 31.0 & 135.5 & 65.4 \\
\hline Human & & & & 48.4 \\
1 & 16.3 & 21.6 & 34.4 & 51.8 \\
2 & 8.6 & 22.5 & 163.9 & 49.8 \\
& 6.1 & 22.0 & 361.3 & 70.5 \\
\hline
\end{tabular}

Propafenone concentration in the reaction mixture $50 \mu \mathrm{M}$. 


\section{Pharmacokinetcs}

Propafenone pharmacokinetics in man and minipigs is presented in Figs. 2A and 2B. The course of the curve for the both species is similar with maximum concentration achieved two hours after intake of propafenone. The propafenone has been eliminated effectively in both species with levels after 24 hours reaching detection limits. What has differed the most was, however, the second phase of the propafenone metabolism. In the man, both metabolites, 5-hydroxypropafenone as well as N-depropylpropafenone have been detected in the plasma (Fig. 2A). On the contrary, in the minipig (Fig. 2B), the amount of $\mathrm{N}$-depropylpropafenone in plasma has been below the limit of quantification and the levels of the main metabolite, 5-hydroxypropafenone, were much lower when compared to levels in the man. As from the in vitro experiment it was known that both the metabolites are formed by minipig microsomal monooxygenases of CYP family (Tab. 1), it has been supposed that this apparent "disappearance" of the metabolites occurred due to an extensive function the enzymes of the second phase of drug biotransformation conjugating effectively the metabolites formed during the first step. That this was really the case has been proven by addition of glucuronidase, an enzyme liberating the metabolites from the conjugates with glucuronic acid. The levels of 5-hydroxypropafenone then have reached the expected values (Fig. 2B). The N-depropylpropafenone levels were below the quantification limit.
This result documents the difference in the function of the enzymes of the second phase of drug biotransformation, namely, of the glucuronosyltransferases, in man and in minipig. What follows directly from the data is that the glucuronosyltransferases of minipig are much more efficient in the conjugation of propafenone metabolites which is however known to occur also in the man ${ }^{11}$. This finding is in line with result of Marini et al. ${ }^{14}$ on high activity of the pig glucuronosyltransferases as well as with earlier results showing the differences between ability of pig glucuronosyltransferases in formation of the same conjugates as in the $\operatorname{man}^{15,16}$.

It seems that the pig (or minipig) enzymes may exhibit an altered substrate specificity and activity in comparison to the enzymes in the man. However, this is more pronounced in the experiments in vivo where all the enzymes involved in drug biotransformation are involved. On the other hand, it should be made clear that also in this case the overall pharmacokinetics of drugs in minipigs exhibit similar course as in the $\operatorname{man}^{11}$. At the subcellular, i.e. microsomal (and possibly also at the cellular ${ }^{17}$ ) level the pigs or minipigs seem to be a good model of drug metabolism in man.

\section{ACKNOWLEDGEMENTS}

Financial support from the Czech Ministry of Education to the COST B 15.50 project is gratefully acknowledged.

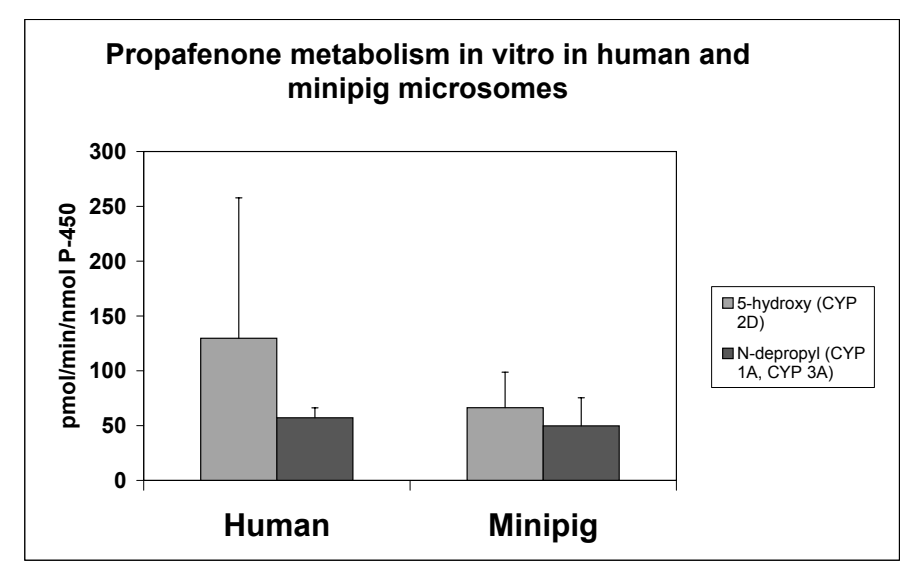

Fig. 1. In vitro metabolism of propafenone in liver microsomal fraction of human and minipig origin. Formation of the 5-hydroxypropafenone by CYP2D (shaded) and N-depropylpropafenone by CYP1A and CYP3A (dark columns) is shown. Data are means \pm S.E.M. from six (minipig) and five (man) experiments. Concentration of propafenone in reaction mixture, $50 \mu \mathrm{M}$ 


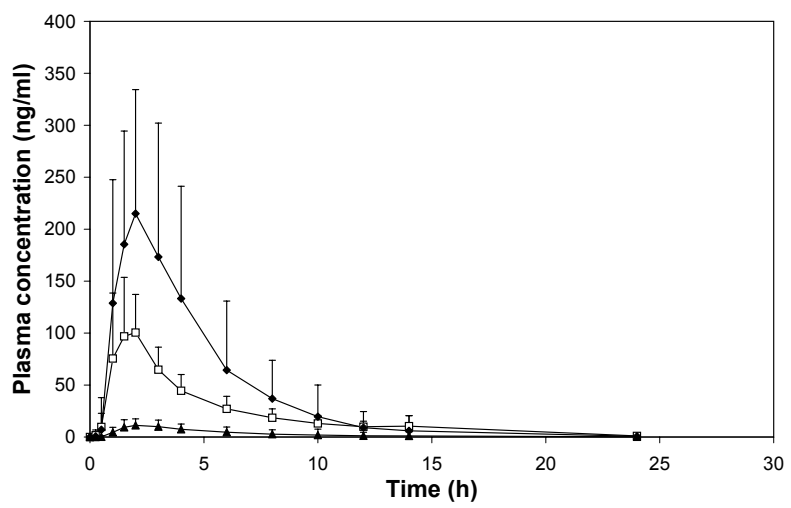

Fig. 2a. Pharmacokinetics of propafenone $(\diamond)$ and its metabolites, 5-hydroxypropafenone ( $\square$ ) and N-depropylpropafenone $(\boldsymbol{\Delta})$ in human plasma.



Fig. 2b. Pharmacokinetics of propafenone $(\downarrow)$ and 5-hydroxypropafenone in minipig plasma before $(\boldsymbol{\Delta})$ and after addition of glucuronosyltransferase $(\square)$.

\section{REFERENCES}

1. Smith AB. (1991) Species differences in metabolism and pharmacokinetics: are we close to an understanding? Drug Metab Rev 23, 355-373.

2. Zuber R, Anzenbacherová E, Anzenbacher P. (2002) Cytochromes P450 and experimental models of drug metabolism. J Cell Mol Medicine 6, 189-198.

3. Anzenbacher P, Anzenbacherová E. (2001) Cytochromes P450 and metabolism of xenobiotics. CMLS, Cell Mol Life Sci 58, 737-747.

4. Lampen A, Christians U, Guengerich FP, Watkins PB, Kolars JC, Bader A, Gonschior AK, Dralle H, Hackbarth I, Sewing KF (1995) Metabolism of immunosuppresant tacrolimus in the small intestine: cytochrome P450, drug interactions, and interindividual variability. Drug Metab Dispos 12, 1315-1324.

5. Monshouwer M, van't Klooster GAE, Nijmeijer SM, Witkamp RF, van Miert ASJPAM. (1998) Characterization of cytochrome P450 isoenzymes in primary cultures of pig hepatocytes. Toxicol in Vitro $12,715-723$
6. Skaanild M, Friis C (1999) Cytochrome P450 sex differences in minipigs and conventional pigs. Pharm Toxicol 85, 174-180.

7. Anzenbacher P, Souček P, Anzenbacherová E, Gut I, Hrubý K, Svoboda Z, Květina J. (1998) Presence and activity of cytochrome P450 isoforms in minipig liver microsomes. Comparison with human samples. Drug Metab Dispos 26, 90-93.

8. Souček P, Zuber R, Anzenbacherová E, Anzenbacher P, Guengerich FP. (2001) Minipig cytochrome P40 3A, 2A and 2C enzymes have similar properties to human analogs. BMC Pharmacology 1 , 16-19.

9. Květina J, Svoboda Z, Nobilis M, Pastera J, Anzenbacher P (1999) Experimental Goettingen minipig and Beagle dog as two species used in bioequivalence studies for clinical pharmacology (5-aminosalicylic acid and atenolol as model drugs). Gen Physiol Biophys $18,80-85$.

10. Anzenbacherová E, Anzenbacher P, Perlík F, Květina J (2000) Use of a propafenone metabolic ratio as a measure of CYP2D6 activity. Int J Clin Pharmacol Therapeutics 38, 426-429.

11. Kroemer HK, Botsch S, Heinkele G, Schick M. (1996) In vitro assessment of various cytochromes P450 and glucuronosyl trans- 
ferases using the antiarrythmic propafenone s a probe drug. Meth Enzymol 272, 99-105.

12. Lake BG characterisation of of microsomal fractions for studies on xenobiotic metabolism. In: Snell K, Mullock B, editors. Biochemical Toxicology. A practical approach. Oxford: IRL Press, 1990. p. 183-215.

13. Vozeh S, Haefeli W, Ha HR, Vlcek J, Follath F (1990) Non-linear kinetics of propafenone metabolites in man. Eur J Clin Pharmacol 38, 509-513.

14. Marini S, Longo V, Mazzaccaro A, Gervasi PG. (1998) Xenobioticmetabolizing enzymes in pig nasal and hepatic tissues. Xenobiotica $28,923-935$.
15. Vree T, Beneken Kolmer EW, Peeters A (1991) Comparison of the metabolism of four sulphonamides between humans and pigs. Vet Q 13, 236-240.

16. Swagler AR, Qian MX, Gallo JM (1991) Pharmacokinetics of anti-HIV nucleotides in microswine. J Pharm Pharmacol 43, 823-826.

17. Olsen AK, Hansen KT, Friis C (1997) Pig hepatocytes as in vitro model to study the regulation of human CYP3A4: Prediction of drug-drug interactions with 17alpha-ethynylestradiol. Chem Biol Interact 107, 93-109. 